\title{
COMPLEX MODEL FOR THE ASSESSMENT OF THE LOCATION OF HIGH-RISE BUILDINGS IN THE CITY URBAN STRUCTURE
}

\author{
Jolanta TAMOŠAITIENE் ${ }^{1}$, Juozapas ŠIPALIS ${ }^{2}$, Audrius BANAITIS ${ }^{3}$ \\ and Ernestas GAUDUTIS ${ }^{4}$ \\ ${ }^{1}$ Department of Construction Technology and Management, Vilnius Gediminas Technical \\ University, Sauletekio al. 11, LT-10223 Vilnius, Lithuania \\ E-mail: jolanta.tamosaitiene@vgtu.lt \\ ${ }^{2}$ Department of Architectural Engineering, Vilnius Gediminas Technical University, \\ Sauletekio al. 11, LT-10223 Vilnius, Lithuania \\ E-mail: juozapas.sipalis@vgtu.lt \\ ${ }^{3}$ Department of Construction Economics and Property Management, Vilnius Gediminas \\ Technical University, Sauletekio al. 11, LT-10223 Vilnius, Lithuania \\ E-mail: audrius.banaitis@vgtu.lt \\ ${ }^{4}$ Department of Architectural Engineering, Vilnius Gediminas Technical University, \\ Sauletekio al. 11, LT-10223 Vilnius, Lithuania \\ E-mail: ernestas.gaudutis@vgtu.lt
}

Received 8 June 2012; accepted 16 August 2012

\begin{abstract}
As the economic conditions in Eastern European countries were changing, so were changing the visions of urban development, which came to be associated with private property and a pursuit of business investments. One of the most important tasks in urban planning today remains efficient models to find a place for high-rise buildings in the urban pattern. The paper aims to identify the most efficient ways to locate high-rise buildings in Vilnius, in reference to many years of related experience of other European cities. Article presents a multi-stage complex assessment model for the location of high-rise buildings in the urban structure. The proposed model is composed from three decision making methods. The first method applied in our research was the SWOT analysis (Strengths, Weaknesses, Opportunities and Threats), which allows assessing current European practices with different models for the location of high-rise buildings in the urban pattern. To determine the weights of criteria reflecting social-economic, political and aesthetic urban planning aspects, the method of expert judgement was used. The next method used was SAW (Simple Additive Weighting), which makes it possible to rank the best alternatives of high-rise buildings location using a pre-selected set of criteria. The research proves that SWOT, expert judgment and SAW are appropriate methods for various kinds of urban planning tasks.
\end{abstract}

KEYWORDS: MCDM; SWOT; Expert judgement; SAW; Model; Location; High-rise buildings

REFERENCE to this paper should be made as follows: Tamošaitienè, J., Šipalis, J., Banaitis, A. and Gaudutis, E. (2013) Complex model for the assessment of the location of high-rise buildings in the city urban structure, International Journal of Strategic Property Management, 17(1), pp. 93-109. 


\section{INTRODUCTION}

The impact of high-rise buildings on urban skylines is becoming more evident; it is a result of individual significant projects that affect urban visual identities. In modern cities, numbers of high-rise buildings differ, depending on the city's political, economic, social, cultural and other features (Alistratovaite, 2005). The development of new high-rise construction was much affected by a transit of Eastern European countries to the market economy, which opened opportunities for private investors to participate in urban development processes. Managing urban development processes to achieve the maximum benefits has become a serious challenge for urban planners and city administrations. The efficiency of new high-rise construction depends on successful location in the urban pattern. High-rise buildings shifted the weight of existing urban centres, creating new urban areas that attract daily commuters and are frequented by other visitors thus ensuring the region's further development and creating attractive business climate for potential investors.

Cities do not exist as isolated or purely random phenomena. Rather each city has a place and a role as an element in a system of cities, which serves a functioning economic and geographical region. Migration processes have an effect on the growth of cities. People want to move where there are social and recreational services and employment opportunities (AlKodmany, 2011b). Eastern European cities have been involved in transition from a centralized political, ideological and economic system to the present reality of a reinstated market economy (Niemczyk, 1998). The position of a city in the international system of cities has a direct impact on its real estate market. In the real estate market, the demand depends on income of the population, changes in the population, turnover of transport technologies and preferences of the population, dynamics of relations among social groups, lending conditions and opportunities (Burinskienè et al., 2011). Large buildings have become an inherent feature of today's growing cities (Helsley and Strange, 2008). Although parcels in the central parts of European cities remain very expensive and construction costs increase depending on a building's height, high-rise buildings remain a profitable investment. Even though the availability of landscape views does not provide a functional attribute, as common facilities do, it is regarded as one of the major determinants of people's home-purchasing decisions, and hence has implications on a home's transaction price (Hui et al., 2012). However one of the biggest threats remains their negative visual impact on urban skylines and territory overshadowing. It has a negative effect on the prices of the surrounding property (Fung and Lee, 2012). Judging from commercial real estate rents and sales prices, downtown and old town areas remain most attractive to investors in the largest European cities. Highrise buildings are, however, not always welcome in historic centres. The location of highrise buildings in an urban structure primarily means that the vision of city's administration and the trends of the real estate market must be reconciled. The interaction between a city's visual identity and the development processes, which often are related only loosely, remains problematic. It makes modern cities appear chaotic and may become ruinous to historic urban areas and urban skylines. The central part of Vilnius may be characterised by poor quality of the living environment, heavy traffic, high concentration of jobs, pollution, conflict between pedestrians and transport. It also has peripheral issues such as undeveloped physical and functional structure, engineering and social infrastructure, insufficient public transport (Burinskienè et al., 2011). It has become evident that a vision of urban development that is closer to the trends in the real estate market could be implemented with 
more ease. Now individual buildings are becoming symbols that mark a new era in urban development (Avraham, 2004). But they are not closely related to the needs of the real estate market, they rather serve as an evidence of the city's apparent prosperity. The development of larger areas using high-rise buildings should be based on the financial capacity of the investors. Another important problem today remains the negative effect of private property on the renewal of larger areas. It is difficult in particular in the central parts of a city, because the existing plots are usually small and have many owners. Facing these challenges, developers seek other alternatives and easier routes to achieve their goals. It may spur uncontrolled activity of developers causing chaos in the city's visual identity and undermining further development of the area. Notably, it is a very relevant problem in cities with a weak legal framework (Daunora et al., 2004). In short, one may contend that a purposeful strategy of urban development ought to be based not only on the composition of urban structures, but also on the current and projected trends of the real estate market.

\section{LOCATION OF HIGH-RISE BUILDINGS: URBAN DESIGN STRATEGIES IN EUROPEAN CITIES}

High-rise buildings first emerged as a profitable investment in real estate, but they were a real reflection of the characteristic symbol creating an image of a modern city. Selecting location for high-rise buildings in urban structure involves considering social, economic, cultural and aesthetic aspects. Problems associated with high-rise buildings, previously typical of other cities in Europe, became important in Lithuania, as it moved from a planned economy to a market economy. Several old European cities with long experience of high-rise construction were selected for the research. The research sets apart such location models for high-rise buildings as dispersed, linear and concentrated. These different location models for high-rise buildings, usual in European cities, were analysed using the SWOT analysis (Strengths, Weaknesses, Opportunities and Threats), popular with many types of problems (see Doratli et al., 2004; Vural-Arslan et al., 2011; Ghazinoory et al., 2011; Zavadskas et al., 2011a).

\section{Dispersed location of high-rise buildings in central part of the city}

It is a model with separate buildings dotting an urban structure; they are defined as landmarks contrasted with the surrounding context in different areas of the city (Daunora et al., 2004; Ikonnikov and Stepanov, 1963; Ikonnikov, 1972). The scale remains an important factor, which allows making architectural volumes part of urban structure; it serves as a contrast measure, providing aesthetic expression (Daunora et al., 2004). It puts emphasis on the key functional and compositional elements of an urban structure. One of the first ideas to use concentrated high-rise buildings was described by Bruno Taut in his book Die Stadtkrone. This model conceived the high-rise as a building in the city centre that towered above everything else. This idea was particularly popular among the champions of the various currents of socialism (Eisele and Kloft, 2003). The image of the Stadtkrone remained a purely theoretical construct. Early in the $20^{\text {th }}$ century a few sketches of high-rise buildings were produced in the Soviet Union as materials for important architectural contests. The emergence of the first high-rise buildings was not a result of the situation in the real estate market. The city needed something to symbolise a new era, a means to consolidate the new political system.

Strength: preserving a valuable part of morphotypes in the city centre. Construction of new large solitary objects in the city centre, 
which is usually characterized by smaller spaces and buildings, allows to preserve the predominant morphotype and the existing diversity of the cityscape (Dixon, 2010).

Weakness: lack of a long-term vision. The negative business impact is a much more dangerous for cities which do not have a long term vision for high-rise buildings development. The important decisions for further high-rise buildings development are taken spontaneous by politicians and to satisfy interests a small group of investors and doesn't guarantee quality results. It's very important to match different aspects of urban planning, particularly in when dealing with dispersed location of highrise buildings.

Opportunity: incorporating the topographic features into the high-rise buildings compositions. It is desirable for buildings to have the individual expression inherent to a particular city. When urban areas are transformed with large buildings, but the topographic features are considered, it is possible to highlight the aesthetic principles of urban planning. A case in point are the works submitted by RMJM London Limited (see Figure 1, a), Rem Koolhaas, Daniel Libenskind, Jean Nouvel and Maksimiliano Fux (see Figure 1, b), and other architects for the Gazprom city contest in Saint Petersburg. A close look at the morphological structure of the natural features makes it possible to use their individual and unique aspects as aesthetic characteristics, creating a versatile visual space.

Threat: a negative visual impact on skylines. New large buildings can cause substantial changes in the overall look of the city, which then would lose its visual identity and get some features of a global city. Tour MaineMontparnasse (architects Jean Soubot, Beaudouin, Cassan, de Marien) in Paris, near the railway station, is considered an obvious mistake of urban planning encouraging prohibitions of high-rise construction in city centres.

\section{Landmarks near important transport nodes}

In classical architecture, the landmark was an object set apart by its mass, height and silhouette complexity. High-rise buildings often serve as accents, used to highlight the city centre, or simply serve as dominant structures, emphasizing the characteristics of the urban fabric (Daunora et al., 2004). The location of high-rise buildings in post-war Moscow is usually given as an example of a system of landmarks (see Figure 1, e, g). The main objective of the city's renewal, based on the ideology of the absolute centre, was to transform the city into the world's first socialist capital. Further development of these cities is inseparable from adding new objects to the system of landmarks or a transition to a mixed location model. It should be noted that in 1990 the Moscow City Government approved adding new towers to the existing system of landmarks.

Strength: this location model for high-rise buildings rests on the features of the transport infrastructure. The aesthetic aspects of territorial planning may be directly linked to the transport infrastructure, as is the case in Moscow (see Figure 1, c). The ring structure of its urban design dictated the location of high-rise buildings that was substantially different from a typical urban fabric of North American cities.

Weakness: the conditions of market economy are unfavourable for the system of landmarks. There are fundamental differences in the way how regulations work in different economic systems. In the market economy it is almost impossible to achieve urban development taking the same direction as the vision conceived by municipal agencies (Daunora et al., 2004).

Opportunity: the system of landmarks makes it possible to create a new visual identity. The scale remains an important factor shaping the skylines of the city's centre; it also serves as a significant accent in the urban pattern. The most common example of landmarks system was offered by El Lissitzky. 


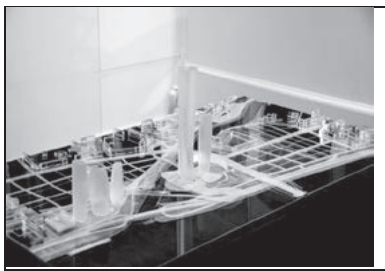

a) Gazprom City architectural competition, the submission by RMJM London Limited (Latur, 2007)

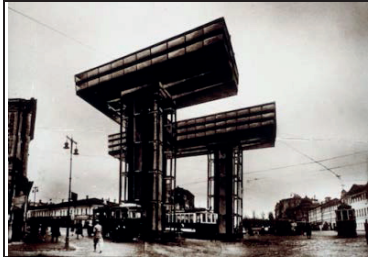

d) A concept of horizontal skyscrapers in Moscow, photomontage

(Eisele and Kloft, 2003)

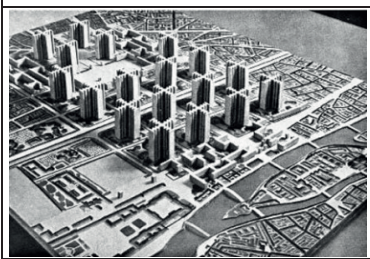

h) Plan Voisin, Paris (Staniūnas, 2005)

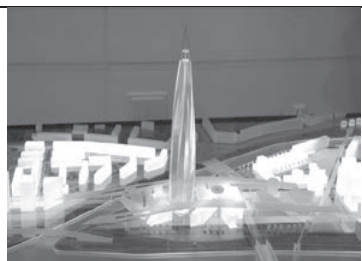

b) Gazprom city architectural competition, the submission by

Maksimiliano Fux (Latur, 2007)

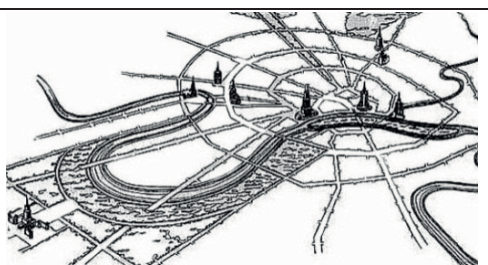

c) Location of high-rise buildings in Moscow's urban structure (Latur, 2007)

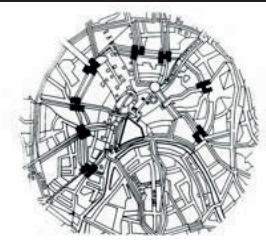

e) Location of horizontal skyscrapers in Moscow's urban pattern (Eisele and Kloft, 2003)

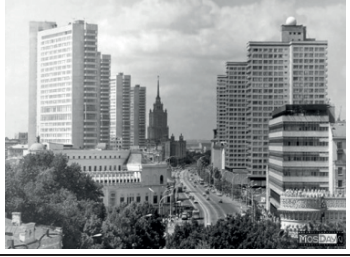

f) A linear cluster in Moscow, New Arbat Avenue (Latur, 2007)

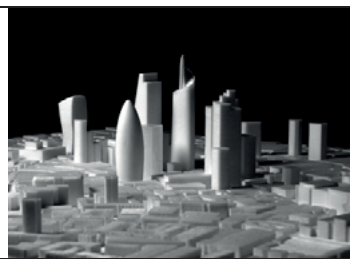

j) A concentrated cluster of high-rise buildings in London's historical centre (Eisele and Kloft, 2003)

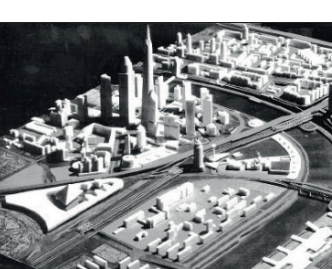

n) Moscow International Business Centre, a model (Latur, 2007) district in the suburbs of Paris, the view of the pedestrian zone (Staniūnas, 2005)

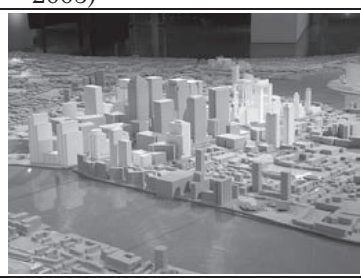

q) Canary Wharf, after

reconstruction

(Eisele and Kloft, 2003)

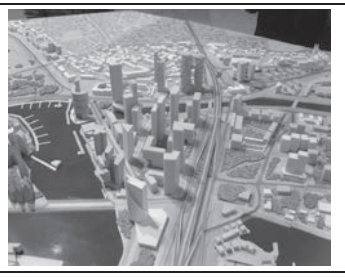

r) High-rise buildings near Riga's historical city centre (Eisele and Kloft, 2003)

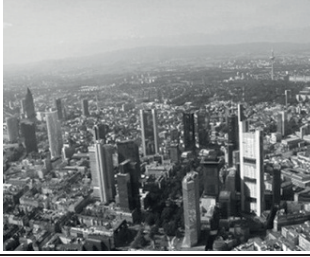

g) A linear cluster in Frankfurt am Main (Eisele and Kloft, 2003)

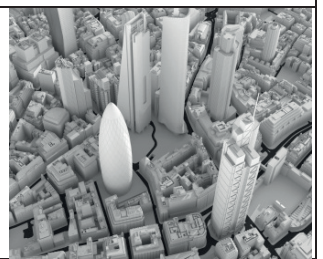

k) A concentrated cluster of high-rise buildings in London's historical centre (Eisele and Kloft, 2003)

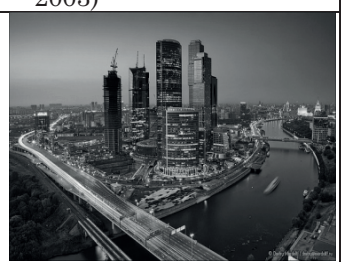

o) Moscow International Business Centre, a panoramic view (Latur, 2007) p) Canary Wha
reconstruction

(Eisele and Kloft, 2003)

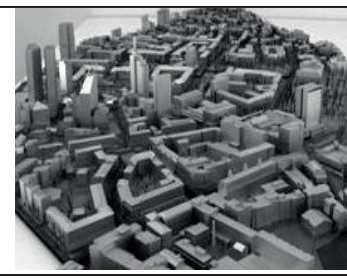

s) A concentrated cluster of high-rise buildings in Tallinn

(Eisele and Kloft, 2003)

Figure 1. Some examples of location models for high-rise buildings in European cities 
Threat: a large number of new scattered objects. A serious threat today is activities of real estate developers driven by fluctuating demands in the real estate market. A cardinal renewal dictates the price per square meter, and city skylines are formed not as part of complex territorial planning solutions, but as individual buildings (Alistratovaitè, 2005). As a result, urban skylines may suffer.

\section{Solitary high-rise buildings in residential areas.}

In post-war years Eastern European countries designed their residential areas focusing on economic and technical aspects, but when construction started gaining pace residential areas lost any touch of individuality in their architectural expression. In urban areas they represent the new order of prosperity and human well-being.

Strength: preserving a valuable part of morphotypes in the city centre and preventing urban areas becoming monotonously unvaried. Taking heed of the unique situation of European cities, urban planners decided, in many cases, in favour of city periphery as a place for construction to preserve the cityscapes that formed historically. The modernist period spoke about the "right" philosophy of architecture, but lost touch with the environment, thus residential areas started to stand out as white spots in the urban context. High-rise buildings became a key elements which allows to avoid assimilation of different districts.

Weakness: negative effects on the quality of living conditions. The problem is that investors are interested in fatter profits above all else, hence they avoid developing urban infrastructure and building social facilities and this may impair the quality of life.

Opportunity: to create better living conditions in urban areas. New suburban construction makes use of the latest technological advances ensuring comfort above that available in any old building in the city's central parts (Staniūnas, 2005). Today the aesthetic visual ecology is starting to play an important role in the ecological design (Chu, 2011). But in Eastern European countries the pursuit of profits undermines the aesthetic aspects when it comes to the planning of residential areas.

Threat: a negative impact on the residential area's visual composition. Compositions are usually regarded as a fully finished arrangement. Chaotic location of new tall residential buildings may ruin the composition of residential areas.

\section{Linear clusters of high-rise buildings along highways}

The linear location of high-rise buildings means that they are lined along the highways crossing a city and become part of the urban pattern as a form of aesthetic expression (Ikonnikov and Stepanov 1963; Ikonnikov 1972; AlKodmany 2011a). It is a way then to create a different, but at the same time continuous image of a city, as illustrated by the central part of Frankfurt (see Figure 1, g). This highlights the city's structural axis, puts an emphasis on the city's external relations and development trends. The most common example is the central part of Moscow (architects M. Posochin, G. Makarevich) where the high-rise buildings line the highway (see Figure 1, f).

Strength: protecting the historical city centre from radical changes. It is one of the ways to locate high-rise buildings in an urban structure and manage the location.

Weakness: bigger transport loads affecting urban transport infrastructure. Locating large scale human attraction objects near important highways has negative effect on transport infrastructure functioning.

Opportunity: to create an image of a city in perpetual movement. Thinking of a city in terms of movement makes transport and communication a very important element, which contributes to the city's image and highlights its aesthetic qualities. The visual perception of an object depends on the observer's position and the conditions for observation. 
Threat: negative effect on the skylines of the city's central areas. Location of large vertical structures close to the historical city centre may damage visually the city's skylines in its central areas.

\section{Concentrated clusters of high-rise buildings in historical city centre}

While skyscrapers were considered an authentic expression of American architecture, urban planners were thinking about ways to find them a place in the old continent. The model of concentrated clusters of high-rise buildings in the city centre means that office buildings are built in urban areas to attract global companies and create better conditions for the global economic elite. Although Europe has always been regarded as the cradle of culture, there are concerns that, with such deep cultural roots, it takes some attributes of other people's identity (Alistratovaitè, 2005). The 20th century saw many debates about the role of high-rise buildings in urban planning. Despite the changes in European cities, their historical parts seemed the most abandoned (Staniūnas, 2005). Historical urban structures were characterized by the narrowest streets restricting access and poor lighting and ventilation. Le Corbusier, one of the first to support skyscrapers, introduced the project known as Plan Voisin, a plan to reconstruct the centre of Paris by demolishing the old town, except for the key buildings, and building skyscrapers swathed in greenery (see Figure 1, h).

American influence is growing in Europe. Illustrations played a key role in the idealization of American cities. Ludwig Karl Hilberseimer grew up in Karlsruhe, a city which is one of the classic examples of an autocratically and geometrically planned city. Karl Hilberseimer, an architect, solved all the traffic problems: public transport is under the ground, vehicular transport on ground level and pedestrian movement at the sidewalks on the fifth level.
Such redevelopment remained an unlikely alternative, because of required investments and a connection with private property. In practice another approach to high-rise construction in the city centre was taken: the construction of skyscrapers as separate buildings transformed into clusters of high-rise buildings (see Figure $1, \mathrm{i}$ ).

Strength: a way to avoid chaotic spread of high-rise buildings. It helps to reconcile the interests of investors and city authorities and to avoid future chaotic location of high-rise buildings.

Weakness: negative visual impact on panoramic views. Large vertical objects in a historical city centre may have a negative visual impact on panoramic views from important observation points. Although the existing historical cityscapes are highly valuable, city authorities, fearing to lose investments, agree to a compromise to create the best possible environment for business development (see Figure $1, \mathrm{j}, \mathrm{k}$ ). One of the most obvious examples is St. Andrews Church in central London and other historical buildings situated there.

Opportunity: to create a compact city core. Compact cities make routes shorter and protect agricultural land from development. It is still one of the key tasks in sustainable urban planning.

Threat: negative impact on valuable morphotypes. New groups of large objects may have a negative impact on historical city centres, as they would change the predominant morphotype.

\section{A concentrated cluster of high-rise buildings as an alternative business district in the city periphery}

Alternative business districts in suburban areas are an attempt to move urban development away from the historic city centre and, at the same time, to develop less attractive urban areas adapting them for new needs brought about by economic growth. 
Strength: unrestricted scale of new construction. Unrestricted scale creates an attractive environment for investors to reach their goals by high-rise construction.

Weakness: a need for large investments into the new district's infrastructure. Infrastructure plays a highly significant role in real estate development in certain areas (Martinus, 2012). This model means that new infrastructure serving the entire area must be created from scratch, which requires considerable investments.

Opportunity: urban development away from historic city centre. The priority of municipal authorities in urban development has remained the need to protect urban areas from uncompromising high-rise construction (Alistratovaitè, 2005). Better conditions to develop business pushed many companies out of the city centre and into new business districts such as La Defense in Paris (architect J. O. Von Spreckelsen; see Figure 1, 1, m).

Threat: emergence of better alternatives for business. The ability to choose an alternative area for high-rise buildings location, especially in the central part of the city, which is characterized by the development of better business opportunities, prevents the growth of new business areas.

\section{Concentrated clusters of high-rise buildings in redeveloped old industrial areas}

Conversion of industrial areas and docklands that lost their purpose could be understood as an attempt to serve the needs of investors. But it is rather a response to the ongoing high-rise construction processes making use of abandoned areas away from the city centre.

Strength: renewal of old unattractive industrial areas. The main task is to adjust industrial areas for new purposes. Old industrial areas that have lost their purpose become a potential place to develop high-rise construction (Carmona, 2009). An example is Canary
Wharf, which, over a period of 35 years, has been involved in radical changes (see Figure 1, $\mathrm{p}, \mathrm{q})$.

Weakness: high-rise buildings location place remains not attractive for investors. Usually these districts are located far away from central part of the city. It has negative effect on investor's interests in territory renewal projects.

Opportunity: to protect historical city centre from radical changes and to develop comprehensive infrastructure necessary to keep a business district running. The key objective is to protect the historical city centre from possible radical changes that might damage its visual identity. The target areas that have lost their purpose are converted to modern business centres with simultaneous development of comprehensive infrastructure and construction of high-rise buildings that serve the needs of modern businesses (see Figure 1, n, o). An example is the Moscow International Business Centre conceived as an idea based on a typical North American city with concentrated clusters of high-rise buildings (architects B. Thor, S. Gusarev, S. Dubrovski, I. Rotburg, G. Sirota).

Threat: emergence of more attractive places for businesses. It is becoming apparent that, unlike the central parts of the city, new business districts created artificially and incorporated into the urban structure are sometimes unable to offer alternative opportunities for business development.

\section{Concentrated clusters of high-rise buildings near historical city centre}

Concentrated clusters of high-rise buildings near historical city centres were analysed by Daunora et al. (2004) and Motieka (2009).

Strength: designing clusters of high-rise buildings based on the local topographic features. The use of topographic features makes it possible to expose expressive urban spaces, as illustrated by the case of Riga (see Figure 1, r). 
Weakness: invalidating an alternative city centre as a cultural space. Along with the physical qualities of the city's central area, other processes are also important, including its cultural life. Downtown remains a key element in the spatial urban structure and is becoming more important as country's economy grows. A concentrated cluster of high-rise buildings needs a large undeveloped area near the historical city centre, which might be an impediment. It is an expression of provincialism, a desire to have something similar to the cities in Western Europe. The location of high-rise buildings should be based on the current and forecasted trends in the real estate market.

Opportunity: to protect the historical city centre from radical changes. The key objective is to protect the historical city centre from possible radical changes that might damage its visual identity.

Threat: the territory turning into an urban conglomerate. When the location is very large and the control of high-rise construction processes inadequate the area may turn into an urban conglomerate, a space dotted chaotically by solitary buildings (see Figure 1, s).

Table 1 outlines the locations of high-rise buildings in the urban structures of some European cities. Table 2 presents an overview of the SWOT analysis.

Today, many European cities use various high-rise buildings location ways. The variety of available models, allows to create different modern cityscapes.

Table 1. Location models for high-rise buildings in European cities

\begin{tabular}{|c|c|c|c|}
\hline $\begin{array}{l}\text { Location of high- } \\
\text { rise buildings in } \\
\text { the urban pattern }\end{array}$ & Location & City, Country & Character \\
\hline \multirow{3}{*}{ Dispersed } & the central part of the city & Barcelona (Spain), Malmo (Norway) & $A_{1}$ \\
\hline & near important transport nodes & Moscow (Russia), Minsk (Belarus) & $A_{2}$ \\
\hline & in suburban residential areas & Moscow (Russia), Vilnius (Lithuania) & $A_{3}$ \\
\hline \multirow[t]{3}{*}{ Linear } & near highways & Moscow (Russia), Frankfurt (Germany) & $A_{4}$ \\
\hline & in the city centre & London (United Kingdom) & $A_{5}$ \\
\hline & in suburban business districts & Paris (France) & $A_{6}$ \\
\hline \multirow[t]{2}{*}{ Concentrated } & in redeveloped old industrial areas & $\begin{array}{l}\text { London (United Kingdom), Moscow } \\
\text { (Russia) }\end{array}$ & $A_{7}$ \\
\hline & $\begin{array}{l}\text { in the modern city centre near the } \\
\text { historical city centre }\end{array}$ & $\begin{array}{l}\text { Riga (Latvia), Vienna (Austria), Tallinn } \\
\text { (Estonia) }\end{array}$ & $A_{8}$ \\
\hline
\end{tabular}

Table 2. The selection criteria defining the location models for high-rise buildings in the urban structure

\begin{tabular}{lllll}
\hline & Strength & Weakness & Opportunity & Threat \\
\hline$A_{1}$ & $\begin{array}{l}\text { Preserving a valuable part } \\
\text { of morphotypes in the city } \\
\text { centre }\end{array}$ & $\begin{array}{l}\text { Lack of a long-term } \\
\text { vision }\end{array}$ & $\begin{array}{l}\text { Incorporating the } \\
\text { transport infrastructure } \\
\text { and topographical features }\end{array}$ & $\begin{array}{l}\text { Negative visual } \\
\text { impact on skylines }\end{array}$ \\
\hline$A_{2}$ & $\begin{array}{l}\text { Location of high-rise } \\
\text { buildings taking into account } \\
\text { the features of transport } \\
\text { infrastructure }\end{array}$ & $\begin{array}{l}\text { The conditions of } \\
\text { market economy are } \\
\text { unfavourable for the } \\
\text { system of landmarks }\end{array}$ & $\begin{array}{l}\text { Makes it possible to create } \\
\text { a new visual identity }\end{array}$ & $\begin{array}{l}\text { A large number } \\
\text { of scattered new } \\
\text { objects }\end{array}$ \\
\hline$A_{3}$ & $\begin{array}{l}\text { Preserving a valuable part } \\
\text { of morphotypes in the city } \\
\text { centre. Prevents urban areas } \\
\text { becoming monotonously } \\
\text { unvaried }\end{array}$ & $\begin{array}{l}\text { Negative effects on } \\
\text { the quality of living } \\
\text { conditions }\end{array}$ & $\begin{array}{l}\text { Makes it possible to create } \\
\text { better living conditions in } \\
\text { urban areas }\end{array}$ & $\begin{array}{l}\text { A negative impact } \\
\text { on the visual } \\
\text { composition }\end{array}$ \\
\end{tabular}




\begin{tabular}{|c|c|c|c|c|}
\hline & Strength & Weakness & Opportunity & Threat \\
\hline \multicolumn{5}{|c|}{ (Continued) } \\
\hline$A_{4}$ & $\begin{array}{l}\text { Protecting the historical city } \\
\text { centre from radical changes }\end{array}$ & $\begin{array}{l}\text { Bigger transport } \\
\text { loads affecting } \\
\text { urban transport } \\
\text { infrastructure }\end{array}$ & $\begin{array}{l}\text { Makes it possible to create } \\
\text { an image of a city in } \\
\text { perpetual movement }\end{array}$ & $\begin{array}{l}\text { Negative effect on } \\
\text { the skylines of the } \\
\text { city's central part }\end{array}$ \\
\hline$A_{5}$ & $\begin{array}{l}\text { A way to avoid chaotic spread } \\
\text { of high-rise buildings }\end{array}$ & $\begin{array}{l}\text { Negative visual } \\
\text { impact on panoramic } \\
\text { views }\end{array}$ & $\begin{array}{l}\text { A way to create a compact } \\
\text { city core }\end{array}$ & $\begin{array}{l}\text { Negative impact } \\
\text { on valuable } \\
\text { morphotypes }\end{array}$ \\
\hline$A_{6}$ & $\begin{array}{l}\text { Unrestricted scale of new } \\
\text { construction }\end{array}$ & $\begin{array}{l}\text { A need for large } \\
\text { investments into } \\
\text { the new district's } \\
\text { infrastructure }\end{array}$ & $\begin{array}{l}\text { Urban development away } \\
\text { from historic city centres }\end{array}$ & $\begin{array}{l}\text { Emergence of better } \\
\text { alternatives for } \\
\text { business }\end{array}$ \\
\hline$A_{7}$ & $\begin{array}{l}\text { Renewal of old unattractive } \\
\text { industrial areas }\end{array}$ & $\begin{array}{l}\text { Location place } \\
\text { remains not attractive } \\
\text { for investors }\end{array}$ & $\begin{array}{l}\text { A way to protect historical } \\
\text { city centres from radical } \\
\text { changes }\end{array}$ & $\begin{array}{l}\text { Emergence of more } \\
\text { attractive places for } \\
\text { businesses }\end{array}$ \\
\hline$A_{8}$ & $\begin{array}{l}\text { Designing clusters of high- } \\
\text { rise buildings based on the } \\
\text { local topographic features }\end{array}$ & $\begin{array}{l}\text { Invalidating an } \\
\text { alternative city centre } \\
\text { as a cultural space. } \\
\text { Difficulties to find } \\
\text { an appropriate size } \\
\text { location for high-rise } \\
\text { construction near the } \\
\text { historical city centre. } \\
\text { A visual imitation of } \\
\text { a foreign city ignoring } \\
\text { regional economic and } \\
\text { social aspects }\end{array}$ & $\begin{array}{l}\text { A way to protect historical } \\
\text { city centres from radical } \\
\text { changes }\end{array}$ & $\begin{array}{l}\text { Private property } \\
\text { inhibits siting of } \\
\text { high-rise buildings }\end{array}$ \\
\hline
\end{tabular}

\section{COMPLEX ASSESSMENT MODEL}

In the modern world the problem solving can be done by assessing not one but several criterion. The complex assessment model can consist from many elements and stages (Tamošaitienè and Zavadskas, 2013). The model the authors propose (see Figure 2) involves the application of three phases:

1) Assessing current European practices for the location of high-rise buildings in the urban pattern with the use of SWOT analysis;

2) Determining the weights of evaluation criteria with the use of expert judgement method (Kendall, 1970); and

3) Ranking the best alternatives of highrise buildings location using a pre-selected set of criteria with the use of SAW method (MacCrimmon, 1968).
In phase (1), different location models for high-rise buildings, usual in European cities, were analysed (see Section 2) using the SWOT analysis (Strengths, Weaknesses, Opportunities and Threats), popular with many types of problems (see Doratli et al., 2004; de Graaf and Dewulf, 2010; Azimi et al., 2011; Vural-Arslan et al., 2011; Fouladgar et al., 2011; Ghazinoory et al., 2011; Zavadskas et al., 2011a). In phase (2), the weights of criteria reflecting social-economic, political and aesthetic urban planning aspects, were determined with the use of experts' assessments (see Table 2). Theoretical and practical aspects of experts' methods in various areas have been dealt with research papers by Hwang and Yoon (1981), Zavadskas (1987), Sivilevičius (2011), Šaparauskas et al. (2011), Klügel (2011), Zavadskas et al. (2010, 2011a,b, 2012), Poplin (2012), Murray et al. (2011). In phase (3), the best 


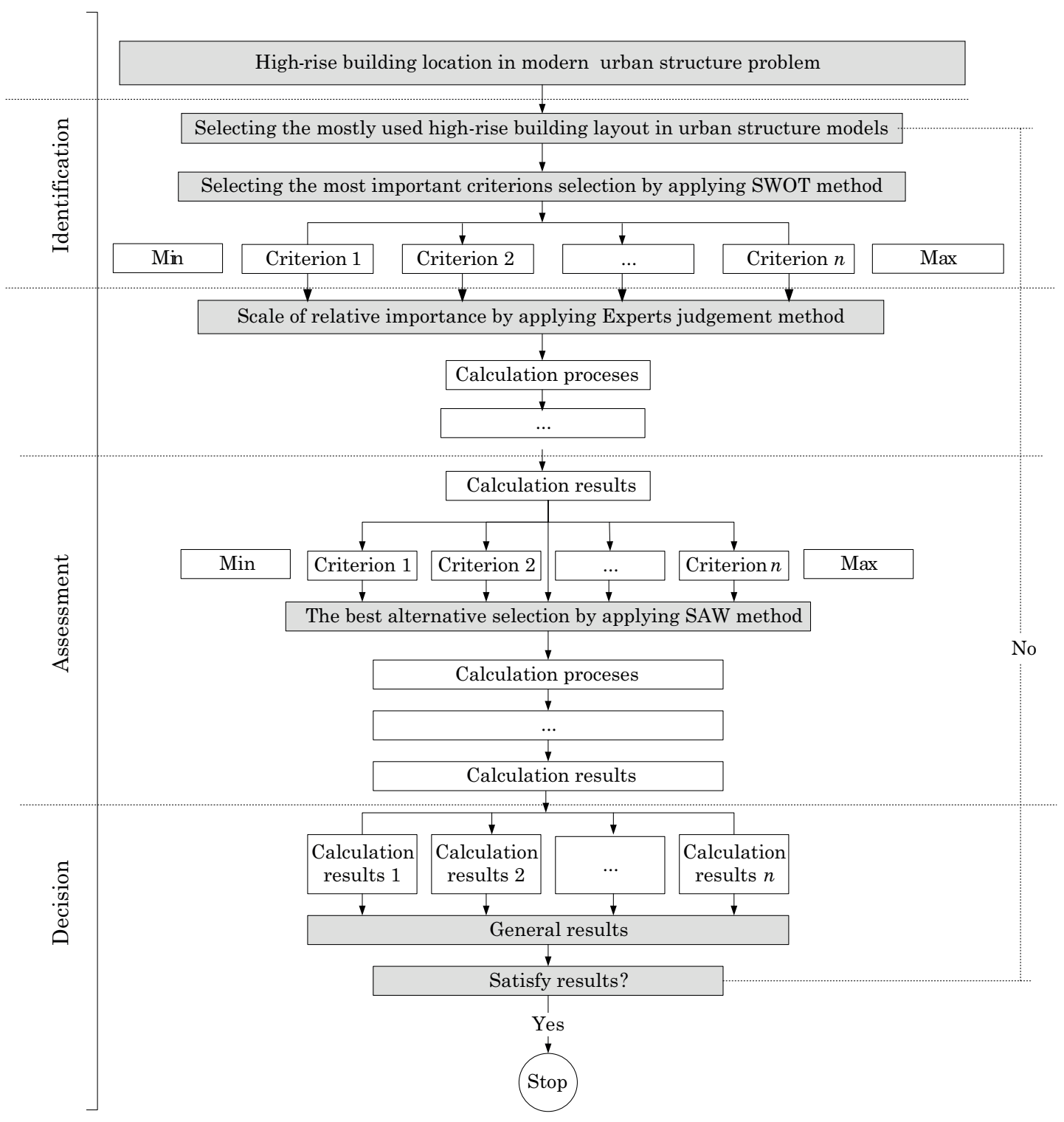

Figure 2. The complex assessment model with SWOT, expert judgement and SAW methods

alternatives of high-rise buildings location using a pre-selected set of criteria were ranked using the SAW method (MacCrimmon, 1968). Theoretical and practical aspects of SAW method in various fields have been dealt with research papers by Banaitiene et al. (2008), Dejjus (2011), Podvezko (2011), Ustinovičius et al. (2012), Chen (2012).

\section{CASE STUDY: THE LOCATION OF HIGH-RISE BUILDINGS IN MODERN VILNIUS}

Urban structure is very sensitive to new large vertical elements. Their emergence has negative impact on cityscapes that formed in the course of history. This case study focuses on the selection of efficient ways to locate high- 
rise buildings in Vilnius, which may help to avoid a chaotic character in the future and create attractive conditions for investors. In Vilnius a high-rise building is any building of 35 meters or above from the ground level. The transition to the market economy created the demand for new large elements in the urban structure, as a way to serve the needs of investors better. The existing locations with highrise buildings should be developed further, taking heed not only of the aesthetic criteria, but also of trends in the property market.

Experience of European cities how to regulate high-rise construction cannot be simply transposed to Vilnius, because of different ur- ban structures and development conditions. The aim is to assess the existing options to locate high-rise buildings, based on the experience of some European cities, and to determine which models are the most efficient for Vilnius. Twelve experts, all working in urban planning, were surveyed to determine the weights. The experts based their assessments on their knowledge, experience and intuition. A scale of 12 points was used for scoring, 12 standing for "very important" and 1 for "not important at all". Priorities of users/owners were demonstrated by the experts as well. Figure 3 shows several possible locations of high-rise buildings in the urban structure of Vilnius.

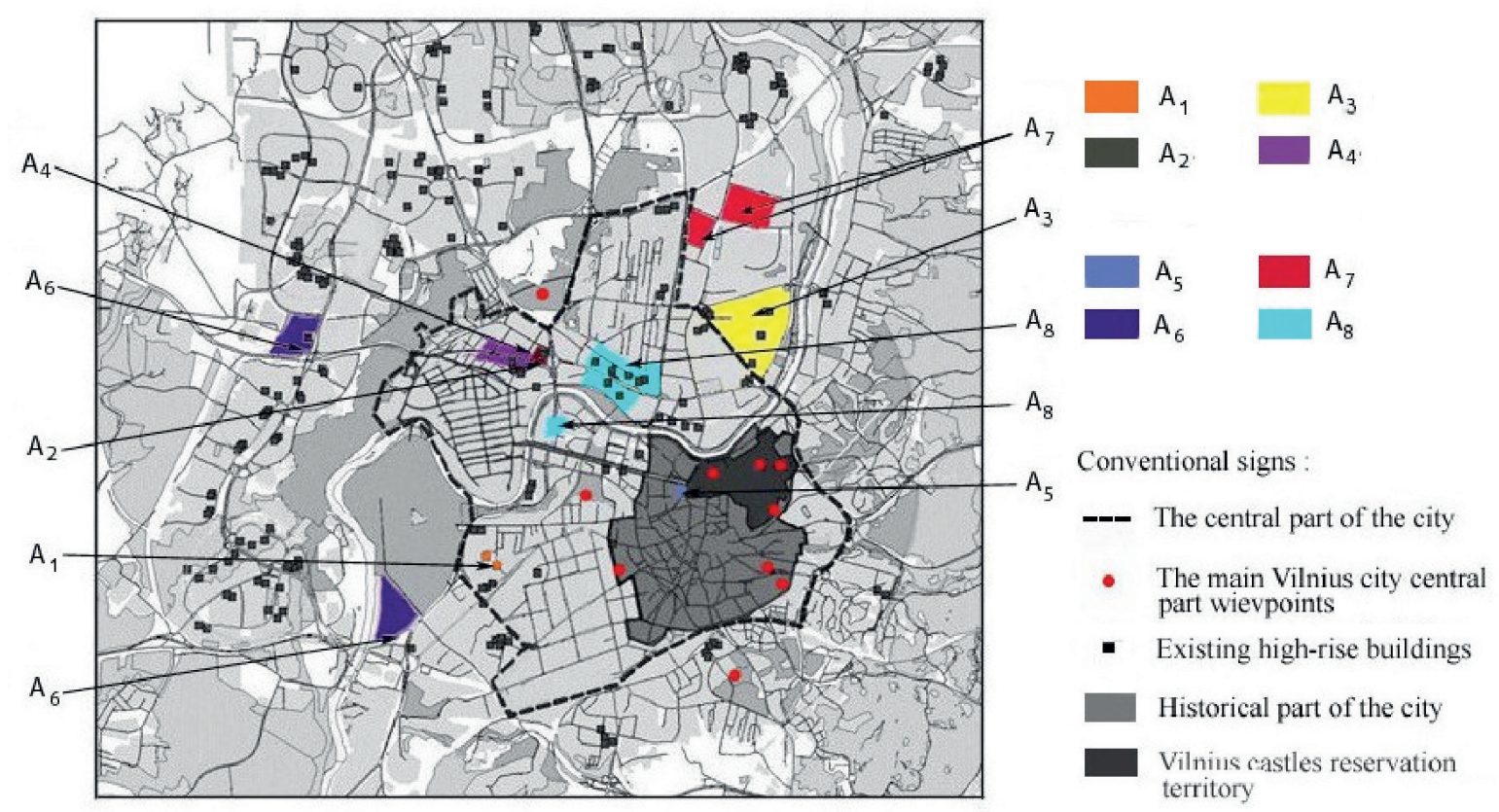

Figure 3. Location models for high-rise buildings: $A_{1}$ - solitary high-rise buildings near the historical city centre; $A_{2}$ - high-rise buildings near important transport nodes; $A_{3}$ - solitary high-rise buildings as dominant structures in residential areas; $A_{4}$ - high-rise buildings lining highways in the city's central part; $A_{5}$ - concentrated clusters of high-rise buildings in the historical centre; $A_{6}$ - concentrated clusters of high-rise buildings in the suburbs; $A_{7}$ - concentrated clusters of high-rise buildings in redeveloped old industrial areas near the city centre; $A_{8}$ - concentrated clusters of high-rise buildings near the historical city centre. 
The main criteria for the assessment are:

$x_{1}$ - preserving valuable morphotypes of the city centre (points);

$x_{2}$ - preventing traffic jams in the central part (points);

$x_{3}$ - regenerating old areas that have lost their purpose (points);

$x_{4}-$ using transport infrastructure as part of the composition (points);

$x_{5}$ - using natural morphotypes to location high-rise buildings (points);

$x_{6}$ - creating attractive conditions for investors (points); $x_{7}-$ negative effect of private property (points);

$x_{8}$ - protecting the historic city centre from radical change (points);

$x_{9}$ - using existing engineering infrastructure in the development of new areas (points);

$x_{10}$ - damage to the skylines of the city centre (points);

$x_{11}$ - chaotic arrangement of high-rise buildings (points);

$x_{12}$ - negative impact of new objects on living conditions (points);

The directions of optimization for the selected attributes are as follows:

$$
\begin{gathered}
x_{1}, x_{2}, x_{3}, x_{4}, x_{5}, x_{6}, x_{8}, x_{9} \stackrel{\text { optimization direction }}{\longrightarrow} \max ; \\
x_{7}, x_{10}, x_{11}, x_{12} \stackrel{\text { optimization direction }}{\longrightarrow} \min ;
\end{gathered}
$$

Table 3. The ranking of the ways to locate high-rise buildings in the urban structure of Vilnius

\begin{tabular}{|c|c|c|c|c|c|c|c|c|c|c|c|c|}
\hline Experts & $x_{1}$ & $x_{2}$ & $x_{3}$ & $x_{4}$ & $x_{5}$ & $x_{6}$ & $x_{7}$ & $x_{8}$ & $x_{9}$ & $x_{10}$ & $x_{11}$ & $x_{12}$ \\
\hline Expert 1 & 11 & 6 & 10 & 8 & 7 & 9 & 2 & 4 & 5 & 12 & 3 & 1 \\
\hline Expert 2 & 11 & 10 & 4 & 7 & 9 & 12 & 2 & 1 & 3 & 8 & 5 & 6 \\
\hline Expert 3 & 12 & 1 & 4 & 5 & 10 & 8 & 2 & 11 & 3 & 9 & 6 & 7 \\
\hline Expert 4 & 12 & 6 & 9 & 8 & 7 & 10 & 2 & 4 & 3 & 11 & 5 & 1 \\
\hline Expert 5 & 11 & 1 & 5 & 4 & 8 & 9 & 3 & 12 & 2 & 10 & 7 & 6 \\
\hline Expert 6 & 12 & 4 & 9 & 8 & 7 & 10 & 2 & 5 & 3 & 11 & 6 & 1 \\
\hline Expert 7 & 12 & 1 & 4 & 5 & 10 & 8 & 2 & 11 & 3 & 9 & 6 & 7 \\
\hline Expert 8 & 12 & 6 & 9 & 8 & 7 & 10 & 2 & 4 & 3 & 11 & 5 & 1 \\
\hline Expert 9 & 12 & 6 & 9 & 8 & 7 & 10 & 2 & 3 & 4 & 11 & 5 & 1 \\
\hline Expert 10 & 11 & 6 & 10 & 8 & 7 & 9 & 2 & 4 & 3 & 12 & 5 & 1 \\
\hline Expert 11 & 11 & 6 & 10 & 8 & 7 & 9 & 2 & 4 & 5 & 12 & 3 & 1 \\
\hline Expert 12 & 11 & 10 & 4 & 7 & 9 & 12 & 2 & 1 & 3 & 8 & 6 & 5 \\
\hline Sum of ranks & 138 & 63 & 87 & 84 & 95 & 116 & 25 & 64 & 40 & 124 & 62 & 38 \\
\hline Average rank & 11.50 & 5.25 & 7.25 & 7.00 & 7.92 & 9.67 & 2.08 & 5.33 & 3.33 & 10.33 & 5.17 & 3.17 \\
\hline Priority & 12 & 5 & 8 & 7 & 9 & 10 & 1 & 6 & 3 & 11 & 4 & 2 \\
\hline $\begin{array}{l}\text { Weight of the } \\
\text { attributes }\end{array}$ & 0.088 & 0.082 & 0.085 & 0.085 & 0.085 & 0.087 & 0.078 & 0.083 & 0.080 & 0.087 & 0.082 & 0.079 \\
\hline
\end{tabular}

Concordance ratio 0.685 ; deviation square sum 14096; concordance rate importance 90.36 ; concordance rate importance 24.72 , expert's opinion consentaneous, recommended apply calculation. 
All decisions involve choosing one of several alternatives. The ways to locate high-rise buildings in the urban structure were ranked using a set of criteria compiled beforehand and the SAW method. Table 3 shows how the ways to locate high-rise buildings in the urban structure of Vilnius were ranked; Table 4 shows the initial decision-making matrix with the values.

Figure 4 shows the siting options ranked by priority using expert judgement and SAW, with the results of calculations.
The alternative $A_{8}$ also ranks highest by its utility degree equal to 0.705 . Concentrated clusters of high-rise buildings near the historical part of the city remain attractive to investors and may help to prevent dispersed construction of new large buildings in the future. The alternative $A_{6}$ with a utility degree of 0.685 ranks second. In this case, the aesthetic qualities of new objects are essential. A modern business district in the suburbs allows protecting valuable elements of the visual identity such as skylines and panoramas,

Table 4. The ways to locate high-rise buildings in the urban structure of Vilnius: the initial decisionmaking matrix with the values

\begin{tabular}{lllllllllllll}
\hline Alternatives & $x_{1}$ & $x_{2}$ & $x_{3}$ & $x_{4}$ & $x_{5}$ & $x_{6}$ & $x_{7}$ & $x_{8}$ & $x_{9}$ & $x_{10}$ & $x_{11}$ & $x_{12}$ \\
\hline$A_{1}$ & 5 & 2 & 6 & 3 & 1 & 7 & 10 & 4 & 9 & 11 & 12 & 8 \\
$A_{2}$ & 12 & 4 & 6 & 8 & 1 & 9 & 7 & 10 & 11 & 2 & 3 & 5 \\
$A_{3}$ & 12 & 9 & 1 & 4 & 7 & 8 & 3 & 10 & 5 & 2 & 11 & 6 \\
$A_{4}$ & 3 & 4 & 1 & 9 & 6 & 8 & 7 & 11 & 10 & 12 & 5 & 2 \\
$A_{5}$ & 3 & 2 & 6 & 7 & 4 & 11 & 10 & 1 & 8 & 12 & 5 & 9 \\
$A_{6}$ & 12 & 10 & 2 & 9 & 8 & 6 & 7 & 11 & 4 & 1 & 5 & 3 \\
$A_{7}$ & 10 & 5 & 12 & 4 & 2 & 8 & 3 & 9 & 6 & 11 & 1 & 7 \\
$A_{8}$ & 8 & 4 & 7 & 9 & 5 & 10 & 2 & 12 & 6 & 11 & 1 & 3 \\
\hline
\end{tabular}

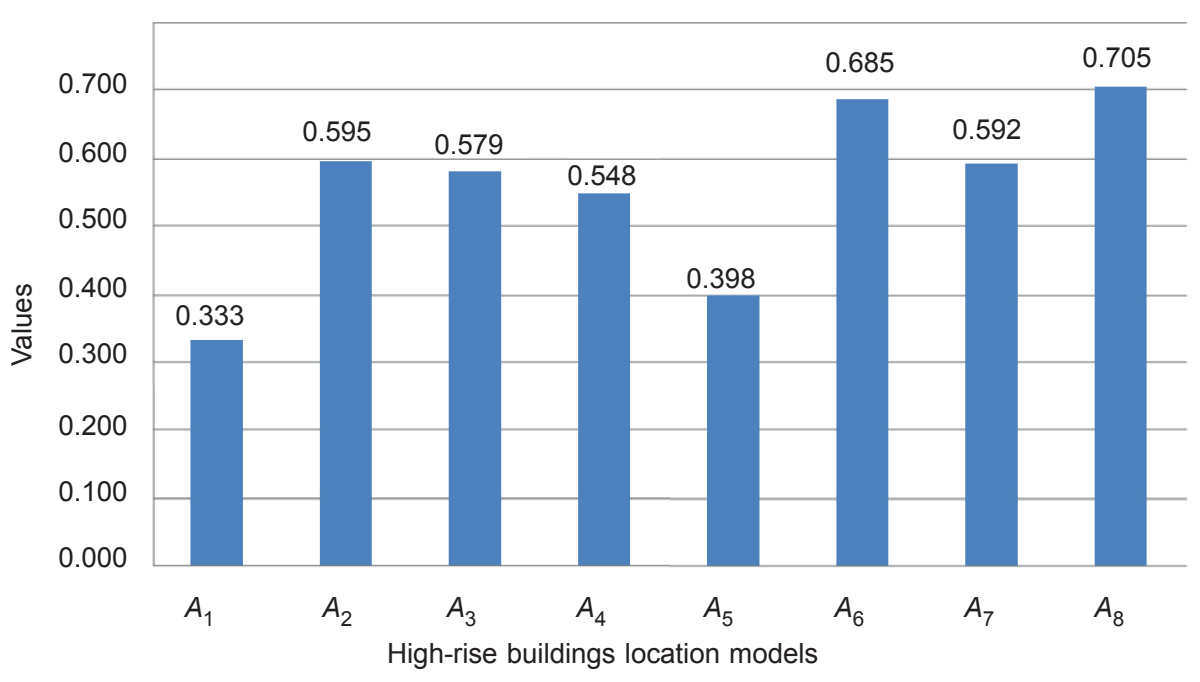

Figure 4. The ways to locate high-rise buildings in the urban structure assessed using the SAW method 
which are the most important elements of cultural identity. The alternative $A_{2}$ with a utility degree of 0.595 ranks third. The alternative $A_{7}$ with a utility degree of 0.592 ranks fourth. Old industrial districts close to the city centre remain a potential location for high-rise buildings, but in Vilnius this opportunity has not been exploited enough so far. The alternative $A_{3}$ with a utility degree of 0.579 ranks fifth. The alternative $A_{4}$ with a utility degree of 0.548 ranks sixth. The alternative $A_{5}$ with a utility degree of 0.398 ranks seventh. Concentrated clusters of high-rise buildings in the historical part of the city are one of the most dangerous solutions as it that may have damage to the historical part. The alternative $A_{1}$ with a utility degree of 0.333 ranks lowest and is eighth, because of its chaotic approach and closeness to the historical city centre. The SAW method produces the following order of alternatives: $A_{8} \succ A_{6} \succ A_{2} \succ A_{7} \succ A_{3} \succ A_{4} \succ A_{5} \succ A_{1}$.

\section{CONCLUSIONS}

In order to assess the ways to locate highrise buildings, a complex assessment system was developed comprising several assessment methods, which are SWOT, expert judgement and SAW. Finding an appropriate way to locate high-rise buildings may make any future urban development process a purposeful effort, prevent chaotic location of high-rise buildings in the city and help create appropriate conditions for investors. The research shows that city planners should continue with the development of concentrated clusters of high-rise buildings near the historical part of the city and concentrated clusters in the city periphery. Construction of solitary buildings near the historical city centre should be avoided.

\section{REFERENCES}

Alistratovaite, I. (2005) Development and preservation of the visual image of the town in the circumstances of globalization, Kultūrologija, 13, pp. 284-307. (In Lithuanian)

Al-Kodmany, K. (2011a) Placemaking with tall buildings, Urban Design International, 16(4), pp. 252-269.

http://dx.doi.org/10.1057/udi.2011.13

Al-Kodmany, K. (2011b) Tall buildings, design and technology: Visions for the twenty-first century city, Journal of Urban Technology, 18(3), pp. $115-140$.

http://dx.doi.org/10.1080/10630732.2011.615573

Avraham, E. (2004) Media strategies for improving an unfavorable city image, Cities, 21(6), pp. 471-479.

http://dx.doi.org/10.1016/j.cities.2004.08.005

Azimi, R., Yazdani-Chamzini, A., Fouladgar, M. M., Zavadskas, E. K. and Basiri, M. H. (2011) Ranking the strategies of mining sector through ANP and TOPSIS in a SWOT framework, Journal of Business Economics and Management, 12(4), pp. 670-689. http://dx.doi.org/10.3 846/16111699.2011.626552

Banaitiene, N., Banaitis, A., Kaklauskas, A. and Zavadskas, E. K. (2008) Evaluating the life cycle of a building: A multivariant and multiple criteria approach, Omega, 36(3), pp. 429-441. http://dx.doi.org/10.1016/j.omega.2005.10.010

Burinskienè, M., Rudzkienè, V. and Venckauskaitè, J. (2011) Effects of quality of life on the price of real estate in Vilnius city, International Journal of Strategic Property and Management, 15(3), pp. 295-311. http://dx.doi.org/10.3846/1 648715X.2011.617857

Carmona, M. (2009) The Isle of Dogs: Four development waves, five planning models, twelve plans, thirty-five years, and a renaissance... of sorts, Progress in Planning, 71(3), pp. 87-151. http://dx.doi.org/10.1016/j.progress.2008.10.001

Chen, T. Y. (2012) Comparative analysis of SAW and TOPSIS based on interval-valued fuzzy sets: Discussions on score functions and weight constraints, Expert Systems with Applications, 39(2), pp. 1848-1861. http://dx.doi. org/10.1016/j.eswa.2011.08.065

Chu, D. (2011) Aesthetic visual ecology and urban landscape planning, Advanced Materials Research, 255-260, pp. 1479-1483. http://dx.doi. 
org/10.4028/www.scientific.net/AMR.255260.1479

Daunora, Z. J., Kirvaitienè, S. and Višniūnas, A. (2004) Vilnius city visual identity protection and development principles. Vilnius: Technika, 152 p. (In Lithuanian)

de Graaf, R. S. and Dewulf, G. P. M. R. (2010) Applying the lessons of strategic urban planning learned in the developing world to the Netherlands: A case study of three industrial area development projects, Habitat International, 34(4), pp. 471-477. http://dx.doi.org/10.1016/j. habitatint.2010.02.005

Dixon, M. (2010) Gazprom versus the skyline: Spatial displacement and social contention in St. Petersburg, International Journal of Urban and Regional Research, 34(1), pp. 35-54. http:// dx.doi.org/10.1111/j.1468-2427.2009.00871.x

Dejus, T. (2011) Safety of technological projects using multi-criteria decision making methods, Journal of Civil Engineering and Management, 17(2), pp. 177-183.

Doratli, N., Hoskara, S. O. and Fasli, M. (2004) An analytical methodology for revitalization strategies in historic urban quarters: A case study for Walled City of Nicosia, North Cyprus, Cities, 21(4), pp. 329-348.

http://dx.doi.org/10.1016/j.cities.2004.04.009

Eisele, J. and Kloft, E. (2003) High-rise manual. Basel: Birkhäuser, 240 p.

Fouladgar, M. M., Yazdani-Chamzini, A. and Zavadskas, E. K. (2011) An integrated model for prioritizing strategies of the Iranian mining sector, Technological and Economic Development of Economy, 17(3), pp. 459-483. http:// dx.doi.org/10.3846/20294913.2011.603173

Fung, Y. W. and Lee, W. L. (2012) Developing a simplified parameter for assesing view obstruction in high-rise high-density urban environment, Habitat International, 36(3), pp. 414-422. http://dx.doi.org/10.1016/j.habitatint.2012.01.001

Ghazinoory, S., Abdi, M. and Azadegan-Mehr, M. (2011) SWOT methodology: A state-of-the-art review for the past, a framework for the future, Journal of Business Economics and Management, 12(1), pp. 24-48. http://dx.doi.org/10.384 6/16111699.2011.555358

Helsley, R. W. and Strange, W. C. (2008) A gametheoretic analysis of skyscrapers, Journal of
Urban Economics, 64(1), pp. 49-64. http:// dx.doi.org/10.1016/j.jue.2007.08.004

Hwang, C. L. and Yoon, K. S. (1981) Multiple attribute decision making, methods and applications. Berlin, Heidelberg, New York: Springer-Verlag. http://dx.doi.org/10.1007/978-3-642-48318-9

Hui, E. C. M., Zhong, J. W. and Yu, K. H. (2012) The impact of landscape views and storey levels on property prices, Landscape and Urban Planning, 105(1-2), pp. 86-93. http://dx.doi. org/10.1016/j.landurbplan.2011.12.002

Ikonnikov, A. V. (1972) Architecture of the city: aesthetic composition problems, 224 p. (In Russian)

Ikonnikov, A. V. and Stepanov, G. P. (1963) Aesthetic of socialist city, 288 p. (In Russian)

Kendall, M. G. (1970) Rank correlation methods (4th ed.). London: Griffin.

Klügel, J. U. (2011) Uncertainty analysis and expert judgment in seismic hazard analysis, Pure and Applied Geophysics, 168(1-2), pp. 27-53. http://dx.doi.org/10.1007/s00024-010-0155-4

Latur, A. (2007) Moscow 1890-2000. Guide to modern architecture. Moscow: Iskusstvo-XXI vek, 440 p. (In Russian)

MacCrimmon, K. R. (1968). Decision making among multiple attribute alternatives: A survey and consolidated approach, RAND Memorandum, RM-4823-ARPA. 70 p.

Martinus, K. (2012) City infrastructure supporting innovation, International Journal of Knowledge-Based Development, 3(2), pp. 126-156. http://dx.doi.org/10.1504/IJKBD.2012.047033

Motieka, S. (2009) Urban model of developing Vilnius modern centre, Urbanistika ir architektūra, 33(4), pp. 195-201. (In Lithuanian) http:// dx.doi.org/10.3846/1392-1630.2009.33.195-210

Murray, J., Thomson, M. E., Cooke, D. J. and Charles, K. E. (2011) Influencing expert judgment: Attributions of crime causality, Legal and Criminological Psychology, 16(1), pp. 126-143. http://dx.doi.org/10.1348/135532510X490183

Niemczyk, M. (1998) City Profile - Warsaw (Warszawa), Cities, 15(14), pp. 301-311. http://dx.doi.org/10.1016/S0264-2751(98)00024-9

Podvezko, V. (2011) The comparative analysis of MCDA methods SAW and COPRAS, Inzinerine Ekonomika-Engineering Economics, 22(2), pp. 134-146. http://dx.doi.org/10.5755/j01.ee.22.2.310 
Poplin, A. (2012) Playful public participation in urban planning: A case study for online serious games, Computers, Environment and Urban Systems, 36(3), pp. 195-206. http://dx.doi. org/10.1016/j.compenvurbsys.2011.10.003

Sivilevičius, H. (2011) Modelling the interaction of transport system elements, Transport, 26(1), pp. 20-34. http://dx.doi.org/10.3846/16484142. 2011.560366

Staniūnas, E. (2005) Changes of town planing regulations in XX century Western Europe. Vilnius: Technika, 144 p. (In Lithuanian)

Šaparauskas, J., Zavadskas, E. K. and Turskis, Z. (2011) Selection of facade's alternatives of commercial and public buildings based on multiple criteria, International Journal of Strategic Property Management, 15(2), pp. 189-203. http://dx.doi.org/10.3846/164871 5X.2011.586532

Tamošaitienè, J. and Zavadskas, E. K. (2013) The multi-stage decision making system for complicated problems, Procedia - Social and Behavioral Sciences (In Press).

Vural-Arslan, T., Dostoglu, N., Koprulu-Bagbanci, O. and Akinciturk, N. (2011) Sustainable revitalisation as a tool for regenerating the attractiveness of an inner-city historic commercial district: 'Han District' as a case, Urban Design International, 16(3), pp. 188-201. http://dx.doi.org/10.1057/udi.2011.1
Zavadskas, E. K. (1987) Complex estimation and choice of resource saving decisions in construction. Vilnius: Mokslas, 212 p. (In Russian)

Zavadskas, E. K., Vilutienè, T., Turskis, Z. and Tamošaitienè, J. (2010) Contractor selection for construction works by applying SAW-G and TOPSIS grey techniques, Journal of Business Economics and Management, 11(1), pp. 34-55. http://dx.doi.org/10.3846/jbem.2010.03

Zavadskas, E. K., Turskis, Z. and Tamošaitienè, J. (2011a) Selection of construction enterprises management strategy based on the SWOT and multi-criteria analysis, Archives of Civil and Mechanical Engineering, 11(4), pp. 1063-1082. http://dx.doi.org/10.1016/S1644-9665(12)60096-X

Zavadskas, E. K., Kaklauskas, A., Turskis, Z., Tamošaitienè, J. and Kalibatas, D. (2011b) Assessment of the indoor environment of dwelling houses by applying the COPRAS-G method: Lithuania case study, Environmental Engineering and Management Journal, 10(5), pp. 637-647.

Zavadskas, E. K., Vainiūnas, P., Turskis, Z. and Tamošaitienè, J. (2012) Multiple criteria decision support system for assessment of projects managers in construction, International Journal of Information Technology \& Decision Making, 11(2), pp. 501-520. http://dx.doi. org/10.1142/S0219622012400135 